\title{
Den skjulte Oldtid - den nye udstilling på Nationalmuseet
}

BRUNO INGEMANN*

Title: The hidden exhibition - The New Prehistory exhibition at The National Museum in Copenhagen.

Abstract: The newly opened Danish National Museum permanent exhibition about the prehistoric period is analysed here from the perspective of the user. The intended narrative of the exhibition is scrutinised in detail, via an analytical construction of how the exhibition meets the visitor, in order to understand why the exhibition at first impression seems so old-fashioned and out of time. The focus in the additional material from the museum is on "... life in Denmark...", and this point of view is promising, but also ends in disappointment. There is so little life in the exhibition that there is only very limited potential for young visitors to explore anything surprising. This is thought-provoking, considering that this exhibition may well be a permanent fixture for the next thirty years.

Key words: Exhibition, analysis, experience, narrative, knowledge, model-visitor, young visitor, prehistory.

Enhver udstilling konstruerer sin besøgende! Man skal som besøgende have bestemte forudsætninger, en vis viden, kende bestemte kategorier, have en bestemt form for nysgerrighed - og det er udstillingen som skaber dette særsprog med dets muligheder for at udelukke eller inkludere den besøgende. Denne artikel ser på nyopstillingen af den danske oldtid på Nationalmuseet i København. I flere år har alle de mange genstande været gemt væk, og i 2008 blev den nye udstilling officielt åbnet. ${ }^{1}$ Hvilken historie fortæller den nye udstilling? Hvem fortæller den til? Hvad kan den besø- gende bruge udstillingen til? Det er de tre spørgsmål denne artikel vil forsøge at give svar på.

\section{OldTIDEN ER GENSTANDE - 12.000}

Vi kan starte med at præsentere den nye udstilling gennem en konkret brugers oplevelse og vurdering af den - og derigennem også få beskrevet udstilling og udstillingssprog, genstande og rum.

Min gode ven Hans er begejstret for 'Den nye Oldtid' på Nationalmuseet. Han er kom- 


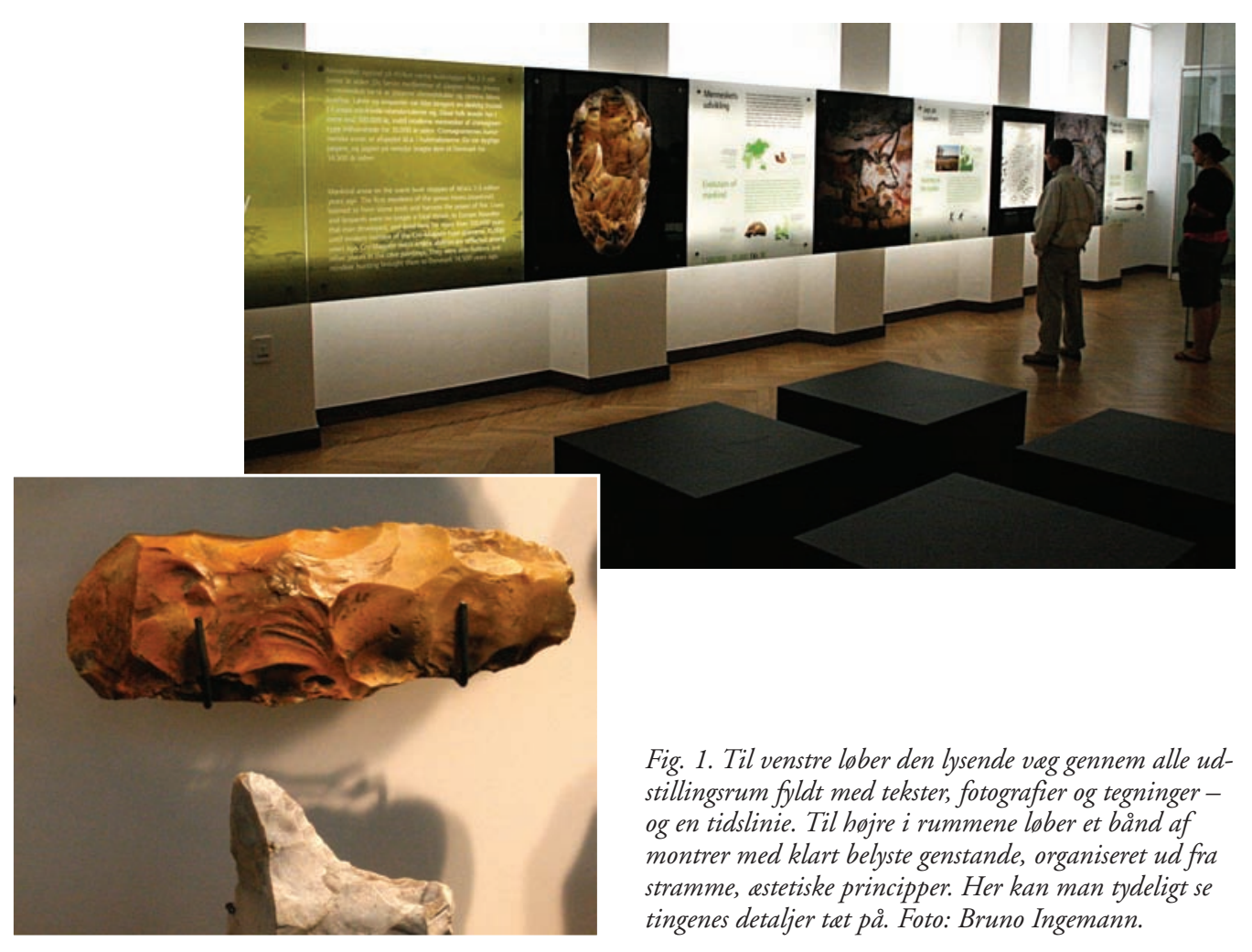

met på Nationalmuseet som barn i fyrrerne med sin far, og han har set den permanente samling og dens genstande mange mange mange gange. Han er nu 67 år, og han glædede sig til at se tingene igen, efter de havde været gemt væk under ombygningen til den nye opstilling. Han er lykkelig for at kunne se tingene, og nu med rigtig godt lys. Han læser ikke en eneste tekst! Det er han ikke interesseret $i$, fordi han selv bærer al den viden, som han har brug for. Min ven Hans er veluddannet og særlig interesseret i historie og er på alle måder den ideelle besøgende i en udstilling som Danmarks oldtid.

Han er fuldt ud tilfreds med genstandene i sig selv. Han har alle de kategorier han har brug for: han kan kronologien, kender den arkæologiske inddeling, kender materialerne, kender næsten hver enkelt genstand; han er lykkelig over, at han nu kan se dobbelt så mange genstande, nemlig 12.000.

Han ser helt hen over eller bort fra de kuratoriske og designmæssige greb. Som $\mathrm{fx}$, at der på den venstre side $\mathrm{i}$ hver enkelt rum er en lange lang frise af kvadratiske 'sider' [1,5 x 1,5 $\mathrm{m}]$ af glas placeret på kraftige lyskasser. Her er der farvesymboler for de tre hovedperioder i oldtiden, en tidslinje, introducerende tekster, fotografier, tegninger og mere detaljerede redegørelser. Og at der i den højre del af rummet er nydesignede montre med godt lys, som tydeligt oplyser de store mængder genstande, der er smukt placeret ud fra æstetiske og designmæssige kriterier.

Min ven Hans er ligeglad. Når bare genstandene er der. Mange genstande. 


\section{KONSTRUKTION AF DEN BESøGENDE}

Min ven Hans er en særlig besøgende. For de fleste af os er det anderledes. Når man kommer første gang til en udstilling, så forsøger man at skabe mening i det ordnede kaos, som en udstilling er - og det sker gennem en ubevidst og næsten Sherlock Holmes-lignende søgen efter spor og tegn.

Det er de tegn og spor, som udstillingens konstruktør, producent, forfatter, designer eller iscenesætter kommer til at lægge frem mere eller mindre bevidst. Derfor kommer enhver udstilling gennem sin form og sit indhold til at konstruere sin egen målgruppe. Ikke gennem intentionelle udsagn, men gennem den helt fysiske og materielle organisering af ting $\mathrm{i}$ forhold til hinanden i rum med brug af designmæssige greb.

Udstillingen skaber ... et billede af udstillingens bruger; det gør den via de kompetencer, som udstillingen kræver, at den besøgende har eller tilegner sig. Vi kan med andre ord tale om udstillingens billede af den besøgende. Denne modelbesøgende er både en teoretisk og analytisk konstruktion, som afspejler de strategier, som udstillingens producent har tiltænkt brugeren. (Ingemann \& Larsen 2005: 241).

Den amerikanske kognitions- og læringsforsker Jerome Bruner mener, at vi prøver at forstå vores omverden gennem to forskellige strategier:

There are two modes of cognitive functioning, two modes of thought, each providing distinctive ways of ordering experience, of constructing reality. The two (though complementary) are irreducible to one another ... One mode, the paradigmatic or logico-scientific one, attempts to fulfil the ideal of a formal, mathematical system of description and explanation. It em-

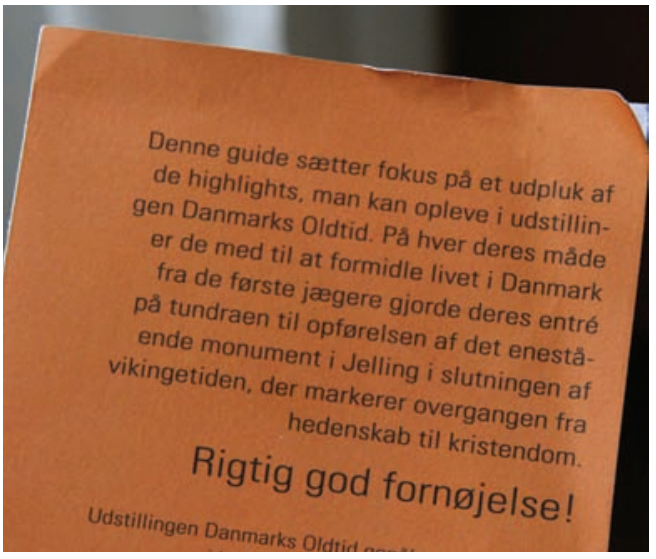

Fig. 2. Folderen, som museets forste tilbud til den besøgende i Oldtidsudstillingen. Det forste tilbud som den besøgende fär med den serlige måde man skal se denne udstilling på - men de centrale ord: '... livet i Danmark'. Foto: Bruno Ingemann.

ploys categorization or conceptualization and the operations by which categories are established, instantiated, idealized, and related one to the other to form a system ... The imaginative application of the narrative mode leads instead to good stories, gripping drama, believable (though not necessarily "true") historical accounts. It deals in human or human-like intention and action and the vicissitudes and consequences that mark their course. (Bruner 1986: 11-13).

Hvis en udstilling skal kunne skabe en narrativ forståelse, så må selve udstillingen tage imod brugeren på en imødekommende måde.

Altså hvordan starter udstillingen? Når man møder noget nyt, har man rigtig travlt, og man skal på ganske kort tid finde ud af, hvad udstillingen handler om; hvilket særligt greb eller strategi udstillingen anlægger; hvad man kan forvente, der kommer til at ske gennem den næste times tid; hvad man mon kan gøre undervejs gennem udstillingen; er der mon 
gode stole at hvile sig på; kan man koble sin nuværende viden sammen med de nye udsagn, som man måske møder, men hvad der er allervigtigst, er hvilke briller skal jeg se med!

I den nye Oldtids-udstilling møder beskueren først en lille folder med teksten 'Danmarks Oldtid på 60 minutter'. Denne tekst giver os en brugervejledning i, hvordan udstillingen skal læses.

Denne guide sætter fokus på et udpluk af de highlights, man kan opleve i udstillingen Danmarks Oldtid. På hver deres måde er de med til at formidle livet i Danmark fra de første jægere gjorde deres entré på tundraen til opførelsen af det enestående monument i Jel- ling i slutningen af vikingetiden, der markerer overgangen fra hedenskab til kristendom. Rigtig god fornøjelse.

\section{"... LIVET I DANMARK"}

Livet handler vel om, at vi fødes, vokser op, arbejder, danner par, avler børn, skaber sociale netværk, ældes og dør ... Hvor gamle blev de? Hvor høje blev de? Fik de mange børn? Hvor mange var de i 'Danmark', og hvordan kan man overhovedet tale om et Danmark i Oldtiden? Hvad levede de af? Bevægede de sig langt fra deres hjem? Hvad troede de på? Den slags gode spørgsmål kan man optimistisk tænke

Fig. 3. Dette er udstillingens anslag: her moder vi udstillingens sarsprog og de kategorier vi skal tenke med. Foto: Bruno Ingemann.

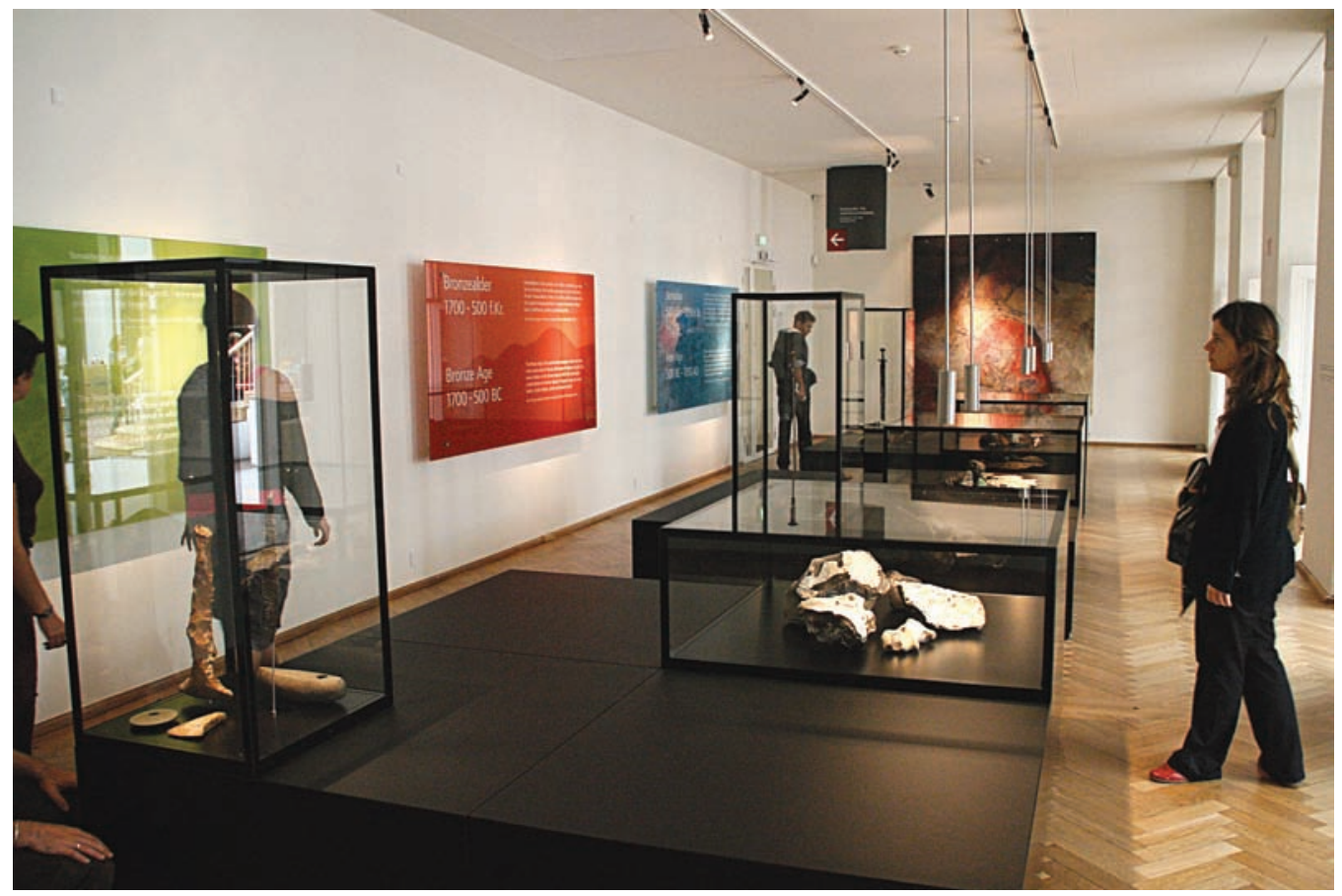


BRUNO INGEMANN

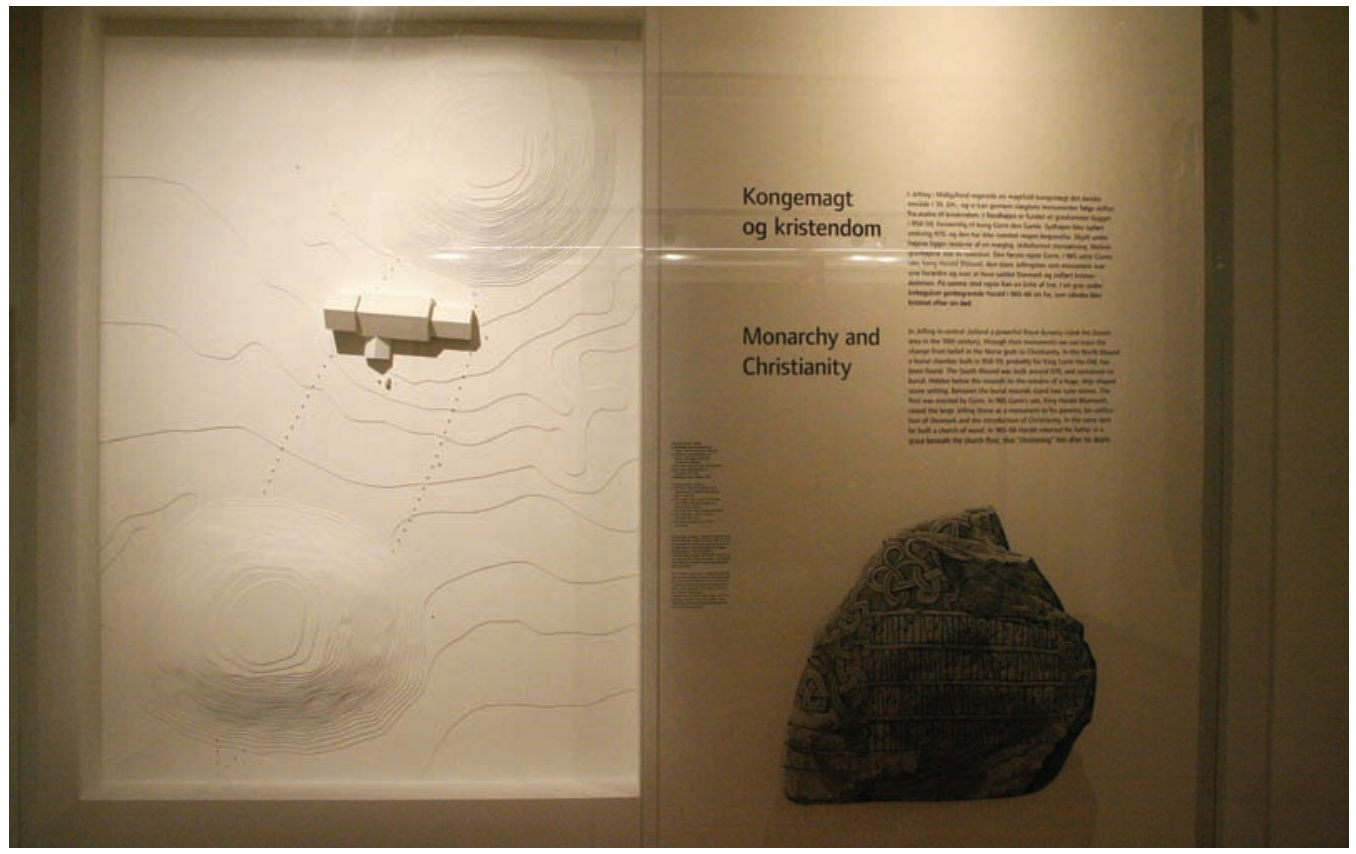

Fig. 4. Udstillingens sidste rum - og en vigtige afslutning - nu er den lysende vag og tidslinien helt vak.

Og hvor blev asatro og kristendom af? Foto: Bruno Ingemann.

bliver skabt ud fra det lille spor med '... livet $\mathrm{i}$ Danmark'. Men er det også sådan udstillingen starter?

Anslaget er meget enkelt: vi skal belæres. Vi skal først og fremmest indføres i denne udstillings særsprog, som her er farven. På væggen hænger tre store lyskasser med hver deres lysende farve: den grønne som skal symbolisere stenalderen; den rødorange som skal symbolisere bronzealderen og den blå som skal symbolisere jernalderen (Fig. 3).

Vi skal lære, hvornår de enkelte tidsinddelinger indgår i den abstrakte tidsmæssige kategori. Vi skal lære, at årsagen til denne inddeling er betinget af brugen af materialer. Dette søges formidlet gennem to montre foran hver tidsperiode: en stor bunke flint i en montre - og i en anden montre er der så tre-fem forskellige genstande, hugget i flint, osv. Der er ingen numre ved hver enkelt ting, ingen genstandstekster, ingen forklaringer på, hvad vi ser andet end et citat fra en bog fra 1836 :

Stenalder indtil 1700 f.Kr. Stenalderen er den periode, hvor våben og redskaber var af sten, træ, knogler og lignende. Der er ingen tvivl om, at denne tid er den $æ l d s t e, ~ h v o r$ mennesker har levet i vore egne. Metal var kun ringe eller slet ikke kendt. I denne periode er de store gravkamre af sten bygget.

Efter Christian Jürgensen Thomsen: Ledetraade i Nordisk Oldkyldighed, 1836.

Det er altså underligt! I et anslag i den gode fortælling eller i den gode film er det centralt 
at få startet hele fortællingen på en præcis måde. Men her er det meget forkølet. Det er en meget forsigtig tekst. Det kan godt være, at man i 1836 var usikker på om denne tid '... er den $x$ ldste, hvor mennesker har levet i vore egne...', men har forskningen i de efterfølgende 172 år ikke givet en mere præcis datering?

De to centrale kategorier våben og redskaber er gennemgående $\mathrm{i}$ beskrivelsen af de tre perioder - og til slut nævnes, at $\mathrm{i}$ jernalderen var der også '... smykker og særlige slags husgeråd.'

Er det mon meningen, at man som beskuer skal gå ind i udstillingen for at blive overbevist eller for at få demonstreret, at våben og redskaber er det der afgørende konstituerer '... livet $i$ Danmark'? Udsagnet er temmelig skuffende. Det er også meget nedvurderende. Det er jo ganske enkelt og selvindlysende, at man kalder en periode for stenalder, bronzealder og jernalder, så har man dette 'materiale-blik' som den adskillende faktor, og denne start giver ikke meget lyst til at fortsætte.

Måske er det symptomatisk, at det rum man starter $\mathrm{i}$, kaldes for rum 0 på folderens plantegning. Det er udenfor den egentlige udstilling. Man kan høre, at mange besøgende udbryder lettet: 'Der starter det!' Når de ser et skilt i den ene ende af dette rum 0 - over en dør, hvor der står 'Indgang til udstillingerne'.

\section{AfsLUTNING - EN FUSER}

Man går gennem udstillingens 24 (+ 0'te) rum og finder et enkelt rum om vikingerne og kommer derefter til det rum, som kunne være det spændende afsluttende rum i den meget lange rundgang. Sammenlagt har man nu været igennem de 12.000 objekter. Det sidste rum bærer titlen Kongemagt og kristendom (Fig. 4). Det er et sært rum. Det domineres af to, nej tre ting. Det et meget lille rum med en kæmpestor arkitektmodel af et landskab med en model af en kirke i Jelling. Det er helt hvidt og lavet af pap. Det hænger på væggen til venstre, når man komme ind i rummet - og på modellen er der nogle små sorte bogstaver med a, b, c, d, e. Og forklaringen står ved siden af, men gør det ikke mere begribeligt, fx står der: a Nordhøjen med gravkammeret opfort i 958-59 og àbnet 965-66.

Hvor vi gennem hele det store udstillingsarealet har prøvet at følge den grundlæggende idé med at lede efter og finde sporene af de tre materielt bestemte tider, så sker der noget helt nyt her i det afsluttende rum. Her er det ikke 'jernalder' men i stedet for finder man arkitektpap og en temmelig indforstået tekst om Gorm den gamle og Jelling og grave og kirke og ... ja, hvor mon det fører hen. Udstillingen slutter nu! Vi skal ud af døren - og her skal vi nøjes med en papmodel og en meget kort tekst, der afslutter Oldtiden med, at 'vi' bliver kristne. Men det er vel egentlig underligt, når definitionen på Jernalderen var brugen af jern

Fig. 5. Disse meget små solvsmykker er hvad der dokumenterer den nordiske mytologi - og konflikten mellem den og kristendommen. Foto: Bruno Ingemann.

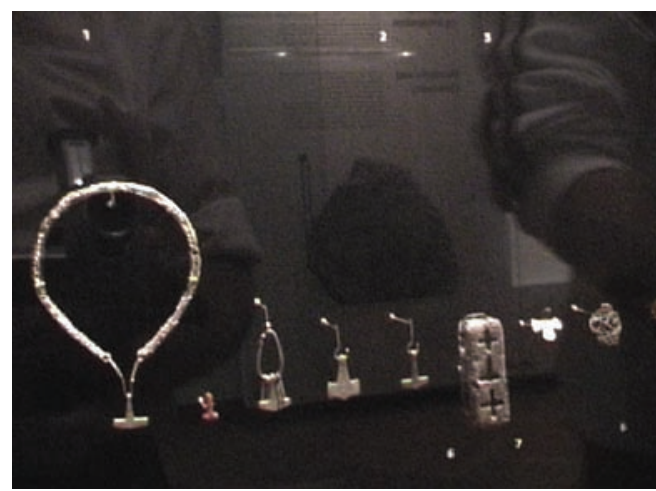




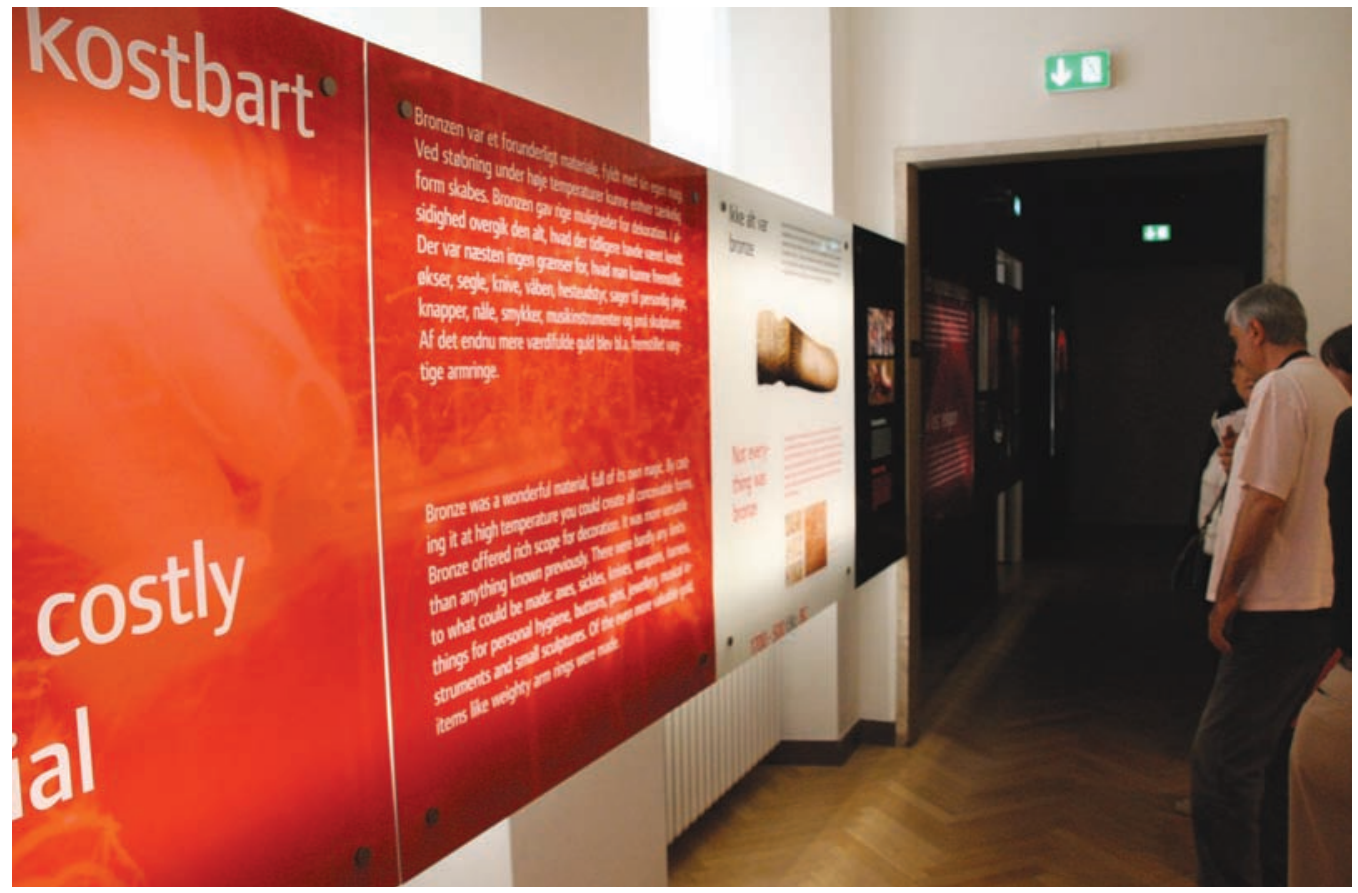

Fig. 6. Den lysende vag kraver lasning - men tilbyder ikke forståelse og indsigt: der er gemt så enorme mangder af viden $i$ de få og generaliserende satninger. Foto: Bruno Ingemann.

til våben og redskaber, så slutter jernalderen pludselig i 1050 e.kr.

Der må åbenbart være nogle andre kriterier på spil, som vist må handle om netop kristendommen som åndelig og verdslig magt. Dette afgørende spil mellem tro på Asa og på Kristus bliver slet ikke foldet ud. Til højre i rummet er der de sædvanlige montre med nogle ganske små genstande - og blandt dem er nogle små smykker med Thors hammer (Fig. 5).

Her står den eneste tekst om:

\section{Asatro til kristendom}

Overgangen fra asa-tro til kristendom foregik langsomt. I 9. årh. var dele af befolkningen kristnet. Da kong Harald i 965 proklamerede kristendommens indførelse havde de to religioner længe levet side om side.

Det afsluttende rum er både meget anderledes end den øvrige udstilling og på samme tid også meget karakteristisk. Der stilles meget høje krav til beskueren, og der fortælles samtidig for lidt til, at man som beskuer kan skabe en sammenhæng mellem det man ved, og det nye man kunne fà at vide.

Tro er da spændende. Hvis man kan skabe en sammenhæng mellem det faglige indhold og al den kommunikation, der i øvrigt foregår i samfundet, så ville det være meget oplagt, at 
Nordisk mytologi kunne udfoldes langt mere end blot med ganske få spredte bemærkninger. For slet ikke at tale om kristendommens indførelse, som ender i en noget tam arkitektmodel. Der fortælles ganske enkelt for lidt til, at man som beskuer kan skabe en sammenhængende fortælling ud fra de stumper som man bliver præsenteret for. Der er ikke meget liv i hverken asatroen eller i kristendommen.

\section{FøRSTE NEDSLAG: FLINT I BRONZEALDEREN}

Der er rigtig mange genstande og rigtig megen tekst gennem hele udstillingen. Det er virkelig en kamp om opmærksomhed. Den uendelig lange og gennemgående lysende væg med tekster og billeder er krævende. Det er som om, at det forventes, at man som beskuer skal læse det hele. Teksten har placeret sig selv midt imellem teksten som et tilbud til læsning og teksten som et krav om læsning. Man kan vælge at læse denne voldsomme lysende væg og så kaste nogle skæve blikke på genstandene - eller man kan opgive den lysende væg og 'nøjes' med at se på de uendeligt mange genstande (Fig. 6).

Det giver nemlig ikke nogen særlige mening at kombinere de to blikke. Der er kun ganske svage sammenhænge mellem den lysende væg og montrene med den store ophobning af genstande. Denne mangel på sammenhæng skaber et meget stort rum for helt private fortolkninger af genstandene og deres relationer til andre genstande. Et eksempel på det finder man næsten halvvejs gennem udstillingen $i$ et rum med titlen 'Bronze - et kostbart råmateriale'.

Men i montrerne, der dækker hele den højre væg i dette rum om bronzealderen, hænger der mange sværd - af flint. En meget lille tekst fortæller, at også i bronzealderen brugte man

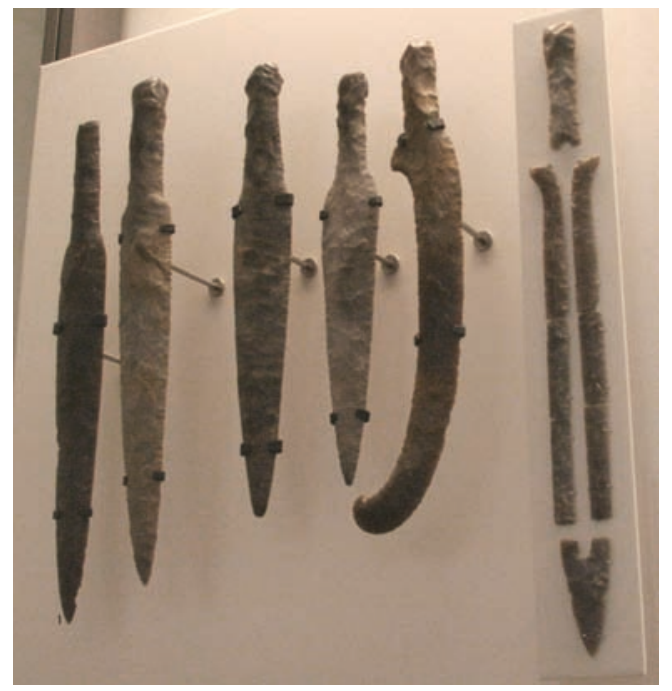

Fig. 7. Hvad er historien med det itubrudte svard?

Foto: Bruno Ingemann.

stadigvæk megen flint til redskaber - og der hænger så et sværd, som helt åbenlyst er gået helt i stykker (Fig. 7). Det består af otte stykker og er hængt op på en særlig plade lidt ud fra væggen. Ud fra vores dagligdagsviden er det da helt naturligt, at et så sprødt materiale som flint ikke kan holde til at blive brugt som sværd, når det er hugget ud i så tynde, spinkle og elegante dele. Det kan også være, at det er blevet ødelagt, fordi det har ligget så længe i jorden eller måske er det ødelagt ved udgravningen.

Der hænger andre sværd ved siden af dette, som også er lavet af flint - men de er hele og mere massive, og det er måske derfor de har holdt bedre? Men de er smukke i formen og alle forskellige. Men nu har vi jo set alle de mange andre dolke og sværd af flint gennem de foregående ti rum, så der er også noget kedeligt velkendt og genkendeligt over opstillingerne. 
BRUNO INGEMANN

Fig. 8. Her hanger

doden $i$ skabet.

Mon de 12 økser

falder ned og skil-

ler kranier fra

kroppe? Foto:

Bruno Ingemann.

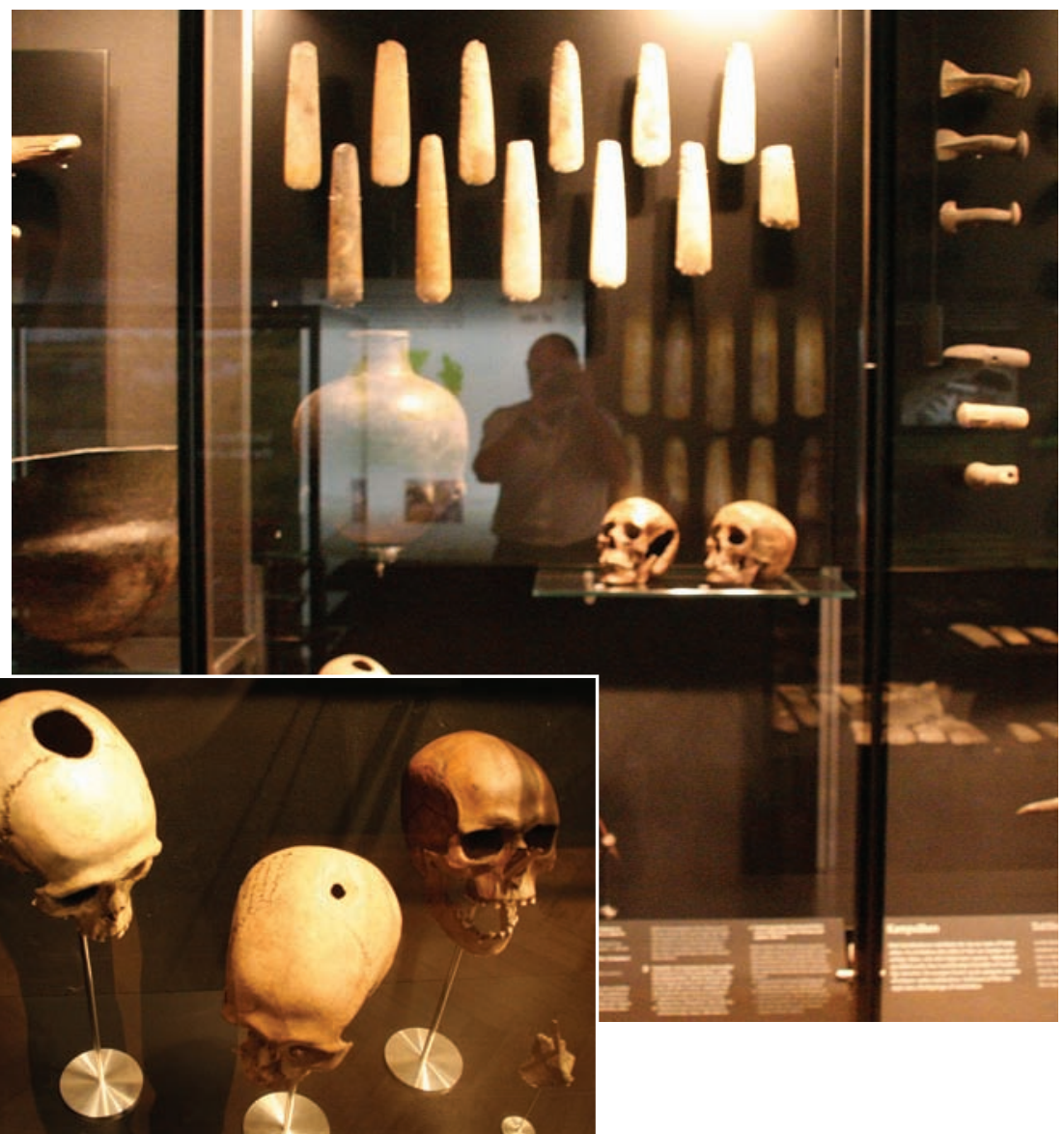

Den lysende væg giver ikke nogle spor, der kan anspore til nye fortolkninger. Og det er jo, hvad man så som beskuer må bruge - sin dagligdagsviden - og på det allerlaveste niveau: at det er smukt eller grimt eller godt eller dårligt håndværk. Hvordan kan man få mere at vide?

Det ANDET NEDSLAG: TREPANATION - ET TAB AF VIDEN OG OPLEVELSE

Det, som ligner en fortælling, består både af tekster, af de udvalgte genstande og den afgørende måde, hvorpå de er placeret i forhold til hinanden. I denne montre med de tolv økser skabes der en fortælling med de rigtig mange store økser, der næsten er på vej ned mod de afhuggede kranier. Det ser voldsomt ud - men også meget æstetisk, statisk og kontrolleret. De tolv økser er, stærkt kontrolleret, ordnet i montren efter et usynligt net af lodrette og vandrette streger (Fig. 8).

Det meget iøjnefaldende i montren er kranierne med de præcise huller. Er det en pil der har boret sig ind her, eller et spyd? Er de to mennesker mon døde af deres skader? Eller er det nogle huller som er lavet med den hensigt at pine dem? Eller er det mon en slags læge- 
kunst? Neden under de tre kranier finder man en tekst, der er meget knap:

\section{Tæt på døden}

Også mennesker blev ofret i den tidlige bondestenalder. To unge piger endte deres dage i en sø, nu Sigersdal Mose i Nordsjælland, den ene med en strik om halsen. I samme mose blev desuden ofret flintøkser og et stort lerkar. Indbyrdes konflikter bønderne imellem kan også have udløst vold og drab. Lægekunst blev praktiseret til behandling af kampskader. Trepanation var en kranieoperation, som i flere tilfælde lykkedes. (2008).

Det er en utrolig komprimeret og tæt tekst: der er ofringer, dels af kvinder, dels af flintøkser og lerkar; dels voldelige konflikter; dels lægekunst. Der er en ophobning af rigtig mange informationer - men netop fordi de er så kompakte og ikke-emotionelle - så taler de mest til den besøgende, som er vidende.

Nationalmuseet skriver på deres hjemmeside, at teksterne er skrevet, ”... så større børn kan læse dem”. Det kan man være temmelig skeptisk over for. Det er ikke en tilstrækkelig kvalitet ved teksten, at den unge kan læse de enkelte ord. Der er også bagvedliggende indhold og forforståelser, der er fraværende og dermed gør det vanskeligt at forstå teksterne. Nogle af kranierne blev oprindeligt brugt til en fortælling i den gamle Oldtids-udstilling fra 1972. Her blev der fortalt langt mere udførligt (Fig. 9.)

\section{Mennesker slog mennesker ihjel.}

Det fortæller disse skeletter af landets første bønder.

Fig. 9. Trepanation bliver i 70'ernes udstilling mere udførligt og mere undersøgende beskrevet. Den besøgende kan tenke sammen med den vidende forsker. Foto: Carsten Tage Nielsen 2006.

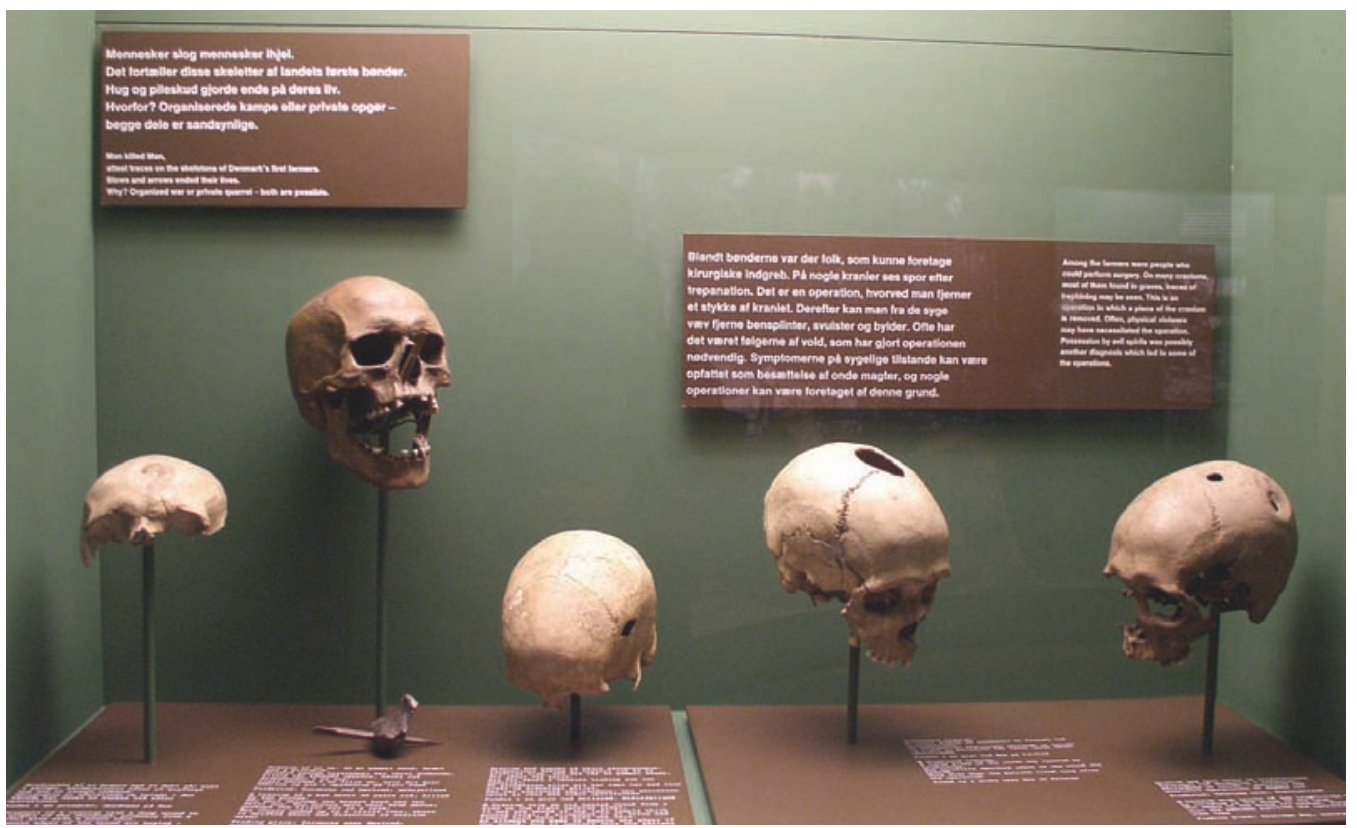


26 Hug og pileskud gjorde ende på deres liv.

Hvorfor? Organiserede kampe eller private opgør begge dele er sandsynlige.

Blandt bønderne var der folk, som kunne foretage kirurgiske indgreb. På nogle kranier ses spor efter trepanation. Det er en operation, hvorved man fjerner et stykke af kraniet. Derefter kan man fra de syge væv fjerne bensplinter, svulster og bylder. Ofte har det været følgerne af vold, som har gjort operationen nødvendig. Symptomerne på sygelige tilstande kan være opfattet som besættelse af onde magter, og nogle operationer kan være foretaget af den grund. (1972).

Forskellen mellem de to tekster (2008 og 1972) er ikke så meget længden. Den største forskel er rigdommen af detaljer og forklaringer. I den ældre tekst kan man fornemme, at her er der en vidende men ikke alvidende person, der skriver specifikt om noget, han eller hun brænder for. Og som stiller spørgsmål og fremviser en vis usikkerhed og formodninger om, hvad der er forklaringerne på de fund man her udstiller. I den nye tekst er autoriteten fraværende som person og er kun postulerende og generel. Der postuleres en sammenhæng mellem de mange flintøkser, krukken, kranierne, - og trepanation kranierne, som faktisk kun eksisterer i kraft af det meget brede tema om 'tæt på døden'.

En udstilling er ikke tekster - men det er en nem kortslutning, at det er gennem teksterne, at vi som besøgende forstår genstandene. Det er ikke teksterne, der er forklaringer, og den måde hvorpå vi kan forstå genstandene og udstillingen. Når Nationalmuseet begejstret skriver, at det tog 18 timer at læse alle teksterne $\mathrm{i}$ 1970 'er udstillingen, og at man i Den nye oldtid kan læse alle tekster på 11/2 time - så har de misset pointen: nemlig at det afgørende er at skabe den grundlæggende ramme, de bril-
Sådan beskriver overinspektør Lars Jørgensen (2008), Nationalmuseet, hvordan udstillingen er opbygget med en tre-deling:

Det første er et baggrundsbelyst bånd, "tidslinien", hvor hovedtekster og det meste grafik er placeret. Udstillingen er stadig kronologisk opbygget, således at forløbet er fremadskridende. Flere steder bliver der dog mere tematiske rum med scenografi, som bryder med det tidsbestemte forløb ...

I rummets midterakse findes fritstående montrer indeholdende oldtidens highlights. I dette forløb er også placeret en række siddemøbler, hvor publikum kan hvile eller betragte udvalgte genstande i highlightmontrerne. Fundene i highlightforløbet vil altid findes omtalt i tidslinien, hvor de ofte er indgang til rummets tema.

Endelig findes modsat tidslinien en montrervæg, hvor der fortrinsvis vil blive udstillet genstandsmængder for at vise mangfoldigheden. Tekstningen vil her primært være genstandstekster suppleret med enkelte grafikindslag. (Jørgensen 2008: 182-184).

ler, som den besøgende skal se med - og de spørgsmål, som løber gennem hele udstillingen - OG at det er gennem sammensætningen af tingene (og ikke teksterne), at denne røde tråd skal kunne fremvises.

\section{DEN SKJULTE UDSTILLING}

Det er på trods af alle de mange valg, som er truffet, at man som besøgende alligevel kan få 
et eller andet ud af denne præsentation. Det er sært og skuffende. Det er en udstilling, der bliver væk, som bliver stadig mere hemmelig og skjult. Der er på mange måde mange larmende elementer. Der er de mange meget flot belyste montre med synlige genstande. ${ }^{2}$ Montrerne fyldes med genstande og stadig flere genstande, som konkurrerer med hinanden om at blive set - og som indeholder en masse skjult viden, som det er umuligt at trække ud af denne voldsomme tingsvæg eller tingsmur. Der bygges nærmest en oldtids-mur mellem den mulige historie og den måske interesserede, men ikke særlig vidende besøgende.

Det er den ene del af det som skjuler udstillingen.

Den anden del er den kæmpe store lysvæg med de mange store påbydende tekster. Som jeg har prøvet konkret at vise, så bliver teksterne mest til ord og tegn som godt nok kan læses og forstås på et meget bogstaveligt plan men teksterne forbliver netop bogstavelige. Det er meget svært at trænge ned under tegnene, og ned til og ind til den viden, som de kommer til at dække over. Det bliver nødvendigt for den besøgende at fungere som arkæolog, ikke kun i forhold til de fremstillede fund og genstande, men også som arkæolog i forhold til de tegn, bogstaver og tekster som i deres abstrakthed er mere tildækkende end åbnende og imødekommende.

\section{Det TREDJE NEDSLAG: DeN LYSENDE VÆEG - OG BLIK UD TIL VERDEN}

Alle danskere har stødt på Skalks tidstavle. En tidstavle afspejler et elementært behov for at relatere det, som er kendt, med noget andet, som nok er kendt, men som vi kender fra mange forskellige sammenhænge. Den pointe er indlejret i den nye udstilling på den lysende

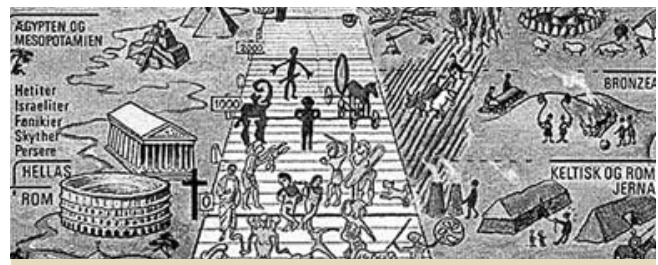

Fig. 10: Her er tidstavlen fra Skalk - den starke popularisering af arkaologi, historie og kulturhistorie har skabt en serlige forståelsesform af tid og udblik.

væg og er helt klart det bedste udstillingsmæssige greb. Det første man ser, når man kommer ind i det lille rum hvor vi er kommet til vikingetiden - er det stort farvefoto af den kæmpestore og meget smukke moské i Konstantinopel.

Det er paradoksalt: at man først opdager dette kuratoriske greb, når man er igennem udstillingen. Det er åbenbart ikke et greb, som er lige så konkret som den gamle Skalktidstavle, hvor man direkte kunne se, at hjemme i bronzealderen var der marker, plove, lurer og jordhytter - og ude var der i Grækenland imponerende templer med søjler. Det hænger nøje sammen med det helt uklare og kedelige anslag i 'Den nye Oldtid' - som ikke åbner for alt det spændende. I det første rigtige udstillingsrum er der klare udblik til Lascaux og hulemalerier, men så er alle udblik glemt, indtil man næsten er igennem hele udstillingen, hvor der så pludselig står noget om romerne.

Men disse udblik rejser flere kritiske spørgsmål: er det mon meningen. at vi skal have noget at vide om andre kulturer i Europa? Hvorfor ikke om Egypten, Mesopotamien, Sydamerika, Kina, Afrika? Skal vi vide det som på Skalk-måden, eller vil man fortælle om, hvad og hvordan kulturelle påvirkninger kom til 
28 Danmark? Udblik er herligt - men hvad er det, som vi skal se "ud på"?

Den besøgende mødes ikke med nogen tydelig intention om, hvad disse udblik skal kunne bruges til - men mødes til gengæld af en voldsom afvisning af den besøgendes indblik. Altså de forforståelser og den viden om oldtiden, man som besøgende bærer med sig. Hvis man har en almindelig common sense opfattelse af oldtid, så vil den historiebevidsthed være fyldt med brokker, hvor nogle af de dominerende elementer vil være vikingerne og den nordiske mytologi.

Man skal virkelig søge med stor omhu for at finde nogle beskedne stumper, der knytter sig til dette meget interessante felt. Fx kan man finde en mørkeblå lyskasse, hvor der er nogle ganske små gengivelser af de helt overmåde fantastiske dyreornamenter, som vi bare ikke får at se som overvældende autentiske genstande, noget som den voldsomme præsentation af meget flint i stenalderen og bronzealderen kunne give løfte om. Det er nedslående. Det må være det vigtigste sted at starte formidlingen, hvor den besøgende er - men i denne udstilling er der meget få historier, der kan forbinde sig til de historier, som man allerede kender fra andre medier og andre sammenhænge.

\section{DER ER JO DE 12 HIGH-LIGHTS?}

Min gode ven går på Nationalmuseet med sit barnebarn. Den lille Frode på 4 år holder sin morfar i hånden og trækker ham af sted:

Hvor er guldhornene?

Hvor er guldhornene?

Hvor er guldhornene?

Frode har sit helt eget highlight - han ved, hvad han går efter og han behøver ikke se andet og mere. Han er målrettet og vidende.

I den lille guide som den besøgende kan få ude i forhallen - kan man få de 12 highlights, som man ifølge museet bør bruge hele $60 \mathrm{mi}-$ nutter på. Det er Egtved-pigen, Solvognen, Gundestrupkarret, Guldhornene - og otte andre genstande. De meget kendte ting er karakteriseret ved en tings-værdi som både ligger i det materiale, som de er lavet af, og af den historie, som der gennem årene er blevet fortalt om dem. De bliver i høj grad strålende og lysende i kraft af hvilke historier, der er forbundet med dem. Derfor er kopierne som før guldhornene værdifulde og spændende, selv om den nyeste historie, om at kopierne blev stjålet igen i 2007, ikke bliver fortalt i udstillingen. I guiden skrives om valget af highlights at '... på hver deres måde er de med til at formidle livet i Danmark.' Eller som der skrives på engelsk i guiden: '... opens the door to a different aspect of early life in Denmark.' Denne oplagte gode idé tabes på gulvet.

Det er faktisk kun udstillingsdelen med Gundestrupkarret, hvor genstanden i sig selv får en sådan scenografisk fremhævelse, at det bliver muligt at få øje på den i al sin storslåethed. Selv Solvognen lykkes det at skabe uopmærksomhed omkring, fordi hele rummet også her overfyldes med andre strålende genstande, og dermed reduceres det mest spektakulære på en ødelæggende måde. Det er rigtig ærgerligt. Det ønske som folderen påpeger med '... hver på deres måde ...', forbliver ganske uklart. Der er 7-8 af de såkaldte highlights, som ikke fremhæves i udstillingsdesignet, og derfor forbliver de temmelig upåagtede og usynlige. De peger heller ikke på sig selv med den særlige indholdsmæssige 'værdi', som de må skulle have for at kunne blive til den særlige kategori, der kan kaldes for et 'highlight'. 
NARRATIV - EN SøGEN EFTER BETYDNING

I brugen af udstillingen kan man analytisk tale om at skabe, blive skabt og bruge udstillingen til at undersøge tre forskellige narrativer: rummets narrativ, kroppens narrativ, det emotionelle narrativ.

Jeg her gennem denne analyse søgt efter og undersøgt, hvordan det mon er muligt at skabe betydning med de ting, rum og tekster, som udstillingen tilbyder - det kan man kalde for rummets narrativ. Det er en udstilling, som næsten gør sig selv usynlig som udstilling, men i langt højere grad er noget ganske andet, nemlig en studiesamling ${ }^{3}-$ som Nationalmuseet skriver på sin hjemmeside $\mathrm{i}$ forbindelse med highlights. Museet gør også opmærksom på, at det har 'en række meget flotte oldtidsklenodier, som de fleste danskere kender og elsker ...' og dermed markerer museet, at Den nye Oldtid er for kendere, og at udstillingen ikke er for dem, for hvem oldtiden virkelig er ny.

Når man er kommet halvvejs gennem Den nye Oldtid - så er man faktisk træt. Man har kun kunnet bruge sin krop ganske lidt i udforskningen af udstillingens rum - det kan man kalde for kroppens narrativ. Man kan gå og stå og læse lysvæggens tekster, og man kan gå og stå og se på genstandene. Man kan tale med sine venner og sidde ned undervejs. Men det som er slående, er det som er fraværende: man kan ikke gøre andet! Her er der ingen digitale medier, ingen knapper man kan trykke på, ingen skærme man kan aktivere, ingen lyd man kan aktivere, intet nyt i hele udstillingsdesignet, der kunne antyde, at man var $\mathrm{i}$ en udstilling fra efter år 2000 - men alt er som det kunne være i en tidligere generation af udstillingen om oldtiden - som den så ud i 1930'erne.
Museet skriver, at teksten skal kunne læses af større børn. Men der skal jo mere til end læsbarhed for at noget bliver vedkommende og relevant for unge. De besøgende må blive emotionelt udfordret af udstillingen - det kan man kalde for det emotionelle narrativ. ${ }^{4}$ Det virker ikke, som om museet har haft tanke på en så specifik målgruppe som unge. Den nye Oldtid er i den grad fokuseret på det arkæologisk faglige, på den uendelige mængde af genstande, på den vidende og måske også ældre besøgende. På den der allerede er entusiastisk engageret!

Det er ærgerligt, at denne nye udstilling kommer til at eksistere i måske 30 år. Man kunne ønske for fremtidens unge, at den blev ændret, justeret og måske endda helt lavet om inden da. Hidtil da må vi leve med Den nye Oldtid.

\section{NOTER}

1. A.P. Møller og Hustru Chastine McKinney Møllers Fond til almene Formaal har givet 36 millioner kroner til at virkeliggøre udstillingen.

2. Det gælder ikke de steder hvor man har lavet meget mørke rum - for her kommer der konflikter og spejlinger af den lysende vægs meget meget kraftige lys. I de rum forsvinder måske de interessante ting.

3. http://www.natmus.dk/sw34914.asp

4. Rummets narrativ, kroppens narrativ og det emotionelle narrativ - er inspireret af The Attention Model (Gjedde \& Ingemann 2008: 115-120).

\section{REFERENCER}

Bruner, Jerome (1986): Actual minds, possible worlds, Cambridge, Mass.: Harvard University Press. Gjedde, Lisa \& Ingemann, Bruno (2008): Resear- 
ching Experiences - exploring processual and experimental methods in cultural analysis. Newcastle: Cambridge Scholar Publishing.

Ingemann, Bruno (2005): 'I sikker havn - konstruktion af en udstilling og den besøgende' in Ingemann, Bruno \& Larsen, Ane Hejlskov (red): $N y$ dansk museologi, Aarhus Universitetsforlag, p. 241-255.

Jørgensen, Lars (2008): 'Den nye Danmarks Oldtid' in Nielsen, Allan Berg (red.): Nye udstillinger $i$ nye rammer, Forlaget Hikuin og Moesgaard Museum, p. 179-188.

Nationalmuseet (2008): Guide: Danmarks Oldtid på 60 minutter.

\section{Diverse:}

Website på www.natmus.dk Anmeldelse i Information: http://www.information.dk/160532 og Nationalmuseets svar http://www.information.dk/ 160608

*Bruno Ingemann, associate professor, ph.d.

Adresse: Centre for Visual Communication

Communication Studies,

Roskilde University,

PO.Box 260,

Denmark

E-mail:bruno@ruc.dk 